Agrovoc descriptors: meloidogyne javanica; nematoda; lycopersicon esculentum; greenhouses; grafting; scions; infection

Agris category code: $\mathrm{H} 10$

COBISS code 1.01

\title{
A case of infection on the scion of grafted tomatoes by the root-knot nematode Meloidogyne javanica
}

\author{
Emmanuel A. TZORTZAKAKIS ${ }^{1}$
}

Received: February 10, 2007; accepted: June 20, 2007.

Prispelo 10. februarja 2007; sprejeto 20. junija 2007.

\begin{abstract}
This is a preliminary communication reporting on a case where the scion of a grafted tomato in a greenhouse crop of Crete became infected by the root-knot nematode Meloidogyne javanica.
\end{abstract}

Key words: greenhouse crop, grafting, nematodes

IZVLEČEK

PRIMER OKUŽBE CEPLJENEGA PARADIŽNIKA Z NEMATODO Meloidogyne javanica

Predhodno poročilo o primeru, da je cepič cepljenega paradižnika v rastlinjaku na Kreti okužila nematoda Meloidogyne javanica.

Ključne besede: vrtnina v rastlinjaku, cepljenje, nematode

\section{INTRODUCTION}

Grafting vegetables on resistant rootstocks is a mean of controlling root-knot nematodes in areas with intensive land use (Lee, 1994; Greco, 1999; Ioannou, 2001; Kacjan Maršić and Osvald, 2004; Lopez-Perez et al., 2006 ).

Despite several grown tomatoes are resistant against the root-knot nematode species Meloidogyne javanica, M. incognita and M. arenaria (Williamson, 1998), the desirable fruit characteristics are not always available in the nematode resistant cultivars. In these cases susceptible varieties with the commercially required characteristics can be grafted onto nematode resistant rootstocks. In Greece the interest in growing grafted plants to control root-knot nematodes, especially in greenhouses, has been increased, but published data are available only for cucumber (Giannakou and Karpouzas, 2003).

1 Nematology Researcher, PhD., Plant Protection Institute, National Agricultural Research Foundation, PO BOX 2228, 71003, Heraklion, Crete, Greece. e-mail: etzortza@her.forthnet.gr 
An investigation of a problem observed in a grafted greenhouse tomato crop is described below.

\section{MATERIALS AND METHODS}

In a greenhouse of Crete with known problem of root-knot nematodes, a tomato crop had been established with a susceptible cv. grafted on a resistant rootstock. That was an evaluation of experimental genotypes under the development to become cultivars by a Seed Company. Many plants remained stunted and chlorotic and produced small fruits. Root samples were brought in the lab and examined.

\section{RESULTS AND DISCUSSION}

Several galls were observed on roots deriving from the scion. In contrast, the rootstock was free of galls but small in size (Figure 1). The galls of the scion root were dissected and revealed the presence of several females and egg masses of root-knot nematodes. The population was identified as M. javanica.

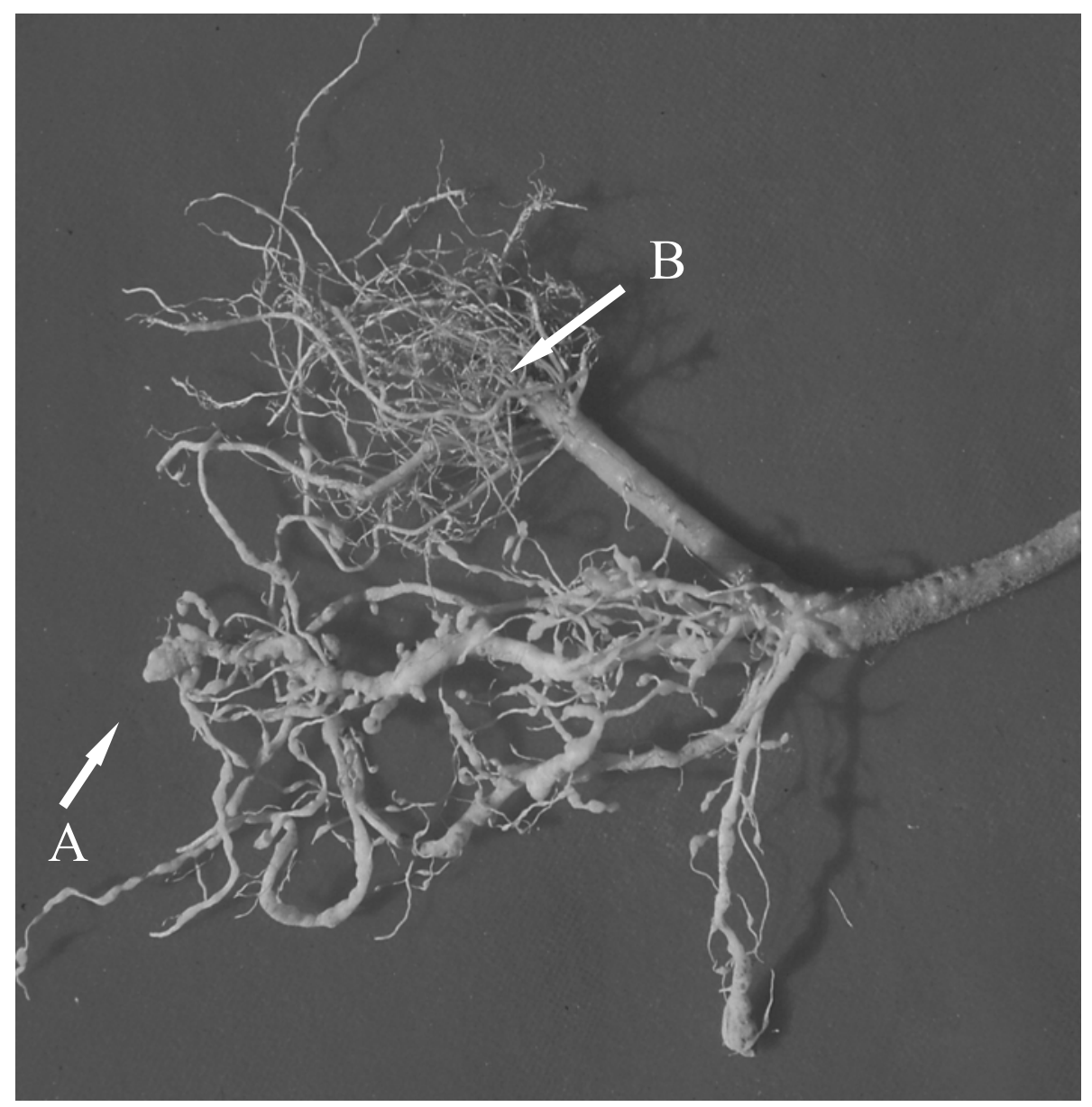

Figure 1. Root galls of $M$. javanica on a root produced by a scion (A) in a grafted tomato plant. The resistant rootstock $(\mathrm{B})$ remained uninfected.

The certain plants had been planted deeply and the point of grafting was very close to the soil surface or had been covered with soil. The great humidity caused rooting of the 
scion and this newly produced root became larger than that of the rootstock and as was susceptible, became infected by nematodes. It is hypothesized that the plant was receiving the majority of water and nutrients from the scion's root system and that explains the appearance of symptoms typical of nematode infection. These problems of scion rooting should be avoided at planting taking care so as the grafting point not to be close to soil surface. Furthermore cultivation techniques should prevent the formation of soil piles around the plant stem.

The use of grafted tomatoes on resistant rootstocks as a mean of managing nematode populations should be investigated in greenhouse crops of Greece. Rotation of resistant tomato with susceptible has been already proved successful for reducing $M$. javanica infestations in greenhouse conditions of Crete (Tzortzakakis et al., 2000). Further research is also required in accessing the susceptibility of tomato rootstocks to resistance breaking pathotypes of Meloidogyne, which have been found infecting resistant tomatoes in both field and experimental conditions (Tzortzakakis et al., 1999, 2000, 2005).

\section{ACKNOWLEDGMENTS}

I thank the agronomist Mr N. Koumartzis who drew my attention to the problem.

\section{REFERENCES}

Giannakou, I.O., Karpouzas, D.G., 2003. Evaluation of chemical and integrated strategies as alternatives to methyl bromide for the control of root-knot nematodes in Greece. Pest Management Science 59: 883-892.

Greco, N., 1999. Alternatives to methyl bromide to control plan parasitic nematodes in greenhouses. In: Proccedings of the $3^{\text {rd }}$ International Workshop on Alternatives to Methyl Bromide for Southern European Countries. Heraclion, Crete, Greece.

Ioannou, N., 2001. Integrating soil solarization with grafting on resistant rootstocks for management of soil-borne pathogens of egg plant. Journal of Horticultural Science and Biotechnology 76: 396-401.

Kacjan Maršić, N., Osvald, J., 2004. The influence of grafting on yield of two tomato cultivars (Lycopersicon esculentum Mill.) grown in a plastic house. Acta agriculturae Slovenica 83: 243-249.

Lee, M., 1994. Cultivation of grafted vegetables. I. Current status, grafting methods and benefits. HortScience 29: 235-239.

Lopez-Perez, J.A., Le Strange, M.., Kaloshian, I., Ploeg, A.T., 2006. Differential response of Mi gene-resistant tomato rootstocks to root-knot nematodes (Meloidogyne incognita). Crop Protection, 25: 382-388.

Tzortzakakis, E.A., Blok, V.C., Phillips, M.S., Trudgill, D.L., 1999. Variation in root-knot nematode (Meloidogyne spp) in Crete in relation to control with resistant tomato and pepper. Nematology 1: 499-506.

Tzortzakakis, E.A., Phillips, M.S., Trudgill, D.L., 2000. Rotational management of Meloidogyne javanica in a small scale greenhouse trial in Crete, Greece. Nematropica 30: 167-175. 
106 Acta agriculturae Slovenica, 89 - 1, avgust 2007

Tzortzakakis, E.A., Adam, M.A.M., Blok, V.C., Paraskevopoulos, C., Bourtzis, K., 2005. Occurrence of resistant breaking populations of root-knot nematodes on tomato in Greece. European Journal of Plant Pathology 113: 101-105.

Williamson, V., 1998. Root-knot nematode resistance genes in tomato and their potential for future use. Annual Review of Phytopathology, 17: 277-293. 